\title{
ANALISIS KARAKTERISTIK DAN KEJADIAN DRUG RELATED PROBLEMS PADA PASIEN HIPERTENSI DI PUSKESMAS TEMINDUNG SAMARINDA
}

\author{
Dwi Sri Handayani, Rolan Rusli, Arsyik Ibrahim \\ Laboratorium Penelitian dan Pengembangan FARMAKA TROPIS Fakultas Farmasi \\ Universitas Mulawarman, Samarinda, Kalimantan Timur \\ email: dwi_shandayani@yahoo.com
}

\begin{abstract}
ABSTRAK
Penelitian ini bertujuan untuk mengetahui gambaran karakteristik pasien hipertensi, dan jenis-jenis serta persentase Drug Related Problems (DRPs) yang terjadi pada pasien hipertensi di Puskesmas Temindung Samarinda. Penelitian bersifat deskriptif, pengambilan data dilakukan secara prospektif pada pasien hipertensi yang memenuhi kriteria inklusi. Data diambil pada periode bulan Februari 2014 melalui rekam medik, wawancara dan pemberian kuisioner.Dari data tersebut selanjutnya dianalisis karakteristik pasien dan adanya kejadian drug related problems (DRPs). Hasil penelitian menunjukkan bahwa penderitahipertensi terbanyak adalah pasien wanita dengan usia 41 hingga 60 tahun, pasien yang memiliki gaya hidup kurang sehat $23,80 \%$, pasien yang memiliki riwayat hipertensi keluarga 63,49 \%. Kejadian Interaksi obat7,5 \%, Adverse Drug Reaction $37,5 \%$, dan ketidakpatuhan pasien $37,5 \%$.
\end{abstract}

Kata Kunci: Hipertensi, Obat Antihipertensi, DrugRelated Problems (DRPs)

\section{PENDAHULUAN}

Hipertensi merupakan salah satu penyakit kardiovaskular dimana penderita memiliki tekanan darah diatas normal yang ditandai dengan nilai sistol lebih dari $140 \mathrm{mmHg}$ dan diastol lebih dari $90 \mathrm{mmHg}$. Hipertensi diperkirakan telah menyebabkan 4,5\% dari beban penyakit secara global, dan prevalensinya hampir sama besar baik di negara berkembang maupun di negara maju.

Hipertensi sering disebut dengan pembunuh diam-diam (silent killer), karena penderita hipertensi mengalami kejadian tanpa gejala (asymptomatic). Hipertensi yang tidak segera dideteksi dan diterapi dapat menyebabkan infark miokard, stroke, gagal ginjal dan kematian.

Prevalensi hipertensi dunia menurut World Health Organisation (WHO) dalam World Health Statistic (2012) mencapai $24,2 \%$ pada laki-laki dan $29,8 \%$ pada perempuan. Prevalensi hipertensi di Indonesia juga tinggi, menurut Survei Kesehatan Rumah Tangga (SKRT) tahun 2001 menunjukkan bahwa 8,3\% penduduk menderita hipertensi dan meningkat menjadi 27,5 \% pada tahun 2004 (Rahajeng, 2009).Berdasarkan Riset Kesehatan Dasar tahun 2013 diketahui prevalensi hipertensi di Indonesia yang didapat melalui pengukuran pada umur $\geq$ 18 tahun sebesar $25,8 \%$, tertinggi di Bangka Belitung (30,9 \%), diikuti Kalimantan Selatan $(30,8 \%)$, dan Kalimantan Timur (29,6 \%) (DEPKES RI, 2013).

Hipertensi merupakan suatu penyakit yang kunci keberhasilan pengobatannya adalah pemilihan dan penggunaan obat. Kegagalan pengobatan terjadi apabila pemilihan dan penggunaan obat tidak sesuai dengan keadaan penderita dan disertai dengan terjadinya Drug Related Problems (DRPs). 
Berdasarkan hal tersebut, untuk memaksimalkan terapi pasien salah satu upaya yang dapat dilakukan yakni menganalisis karakteristik dan kejadian Drug Related Problems (DRPs) pada pasien hipertensi di Puskesmas Temindung Samarinda.

\section{METODE PENELITIAN}

\section{Alat dan Bahan Penelitian}

Kartu rekam medis pasien, kuisioner, dan lembar pengumpul data.

\section{Populasi dan Sampel Penelitian}

Populasi penelitian ini adalah seluruh pasien hipertensi yang menjalani pengobatan di Puskesmas Temindung selama periode bulan Februari tahun 2014. Sampel dalam penelitian ini adalah pasien hipertensi di Puskesmas Temindung yang memenuhi kriteria inklusi. Pengambilan sampel dari polulasi dilakukan dengan teknik nonrandom sampling dengan menggunakan metode purposive sampling.

Kriteria inklusi sampel yaitu :

a. Pasien hipertensi yang rutin melakukan pengobatan di Puskesmas Temindung Samarinda

b. Pasien hipertensi rawat jalan pada periode Februari 2014

c. Pasien yang memiliki data rekam medik yang lengkap

d. Pasien hipertensi dengan atau tanpa penyakit penyerta

e. Pasien yang bersedia menjadi responden dalam penelitian

\section{Prosedur Penelitian}

Penelitian diawali dengan observasi jumlah pasien hipertensi, kemudian sampel ditentukan dari populasi pasien yang memenuhi kriteria inklusi. Pengambilan data dilakukan dengan pencatatan rekam medik. Kekurangan data pada rekam medik dilengkapi dengan wawancara dan pemberian kuisioner kepada pasien atau keluarga pasien. Data yang diperoleh dianalisis secara deskriptif, yaitu karakteristik pasien dan kejadian DRPS setiap kategori dengan perhitungan :

$\%$ Kejadian $=\mathrm{F} / \mathrm{P} \times 100 \%$

Keterangan :

$\mathrm{F}=$ Frekuensi kejadian

$\mathrm{P}=$ Total Populasi sampel

\section{HASIL DAN PEMBAHASAN}

\section{Gambaran Karakteristik Pasien Hipertensi}

Penelitian ini dilakukan di Puskesmas Temindung Samarinda. Responden yang dikumpulkan pada penelitian ini sebanyak 63 orang. Dari 63 responden tersebut selanjutnya dianalisis karakteristiknya berdasarkan usia, jenis kelamin, gaya hidup (kebiasaan olahraga, merokok, dan konsumsi alkohol), dan adanya riwayat hipertensi keluarga.

Gambaran distribusi pasien hipertensi di Puskesmas Temindung berdasarkan jenis kelamin dan usia disajikan dalam Gambar 1.

Berdasarkan Gambar 1, diketahui bahwa pasien dengan usia 41 hingga 60 tahun baik pada perempuan ataupun lakilaki lebih banyak menderita hipertensi dibandingkan dengan usia muda. Semakin tua seseorang maka arteri akan kehilangan elastisitasnya yang menyebabkan kemampuan memompa darah berkurang sehingga tekanan darah meningkat. Sebenarnya wajar apabila tekanan darah meningkat dengan bertambahnya usia karena hal tersebut disebabkan oleh perubahan alami pada jantung, pembuluh darah, dan hormon (Nugraha dkk, 2011).

Berdasarkan Gambar 1 juga diketahui bahwa perempuan lebih banyak menderita hipertensi dibandingkan dengan laki-laki. Hal tersebut diduga karena wanita lebih mudah stres dibandingkan dengan pria (Gunawati, 2006). Stres dapat menstimulasi aktivitas syaraf simpatis sehingga meningkatkan resistensi 
pembuluh darah perifer dan curah jantung. Selain itu wanita dengan usia diatas 40 tahun akan mengalami menopause, sehingga hormon estrogen akan menurun. Penurunan estrogen dapat meningkatkan tekanan darah karena estrogen berperan melawan hipertensi melalui penghambatan jalur vasokontriktor oleh sistem syaraf simpatik dan angiotensin (Mutmainah dan Mila, 2010).

Gambaran distribusi pasien hipertensi di Puskesmas Temindung berdasarkan gaya hidup disajikan dalam Gambar 2.

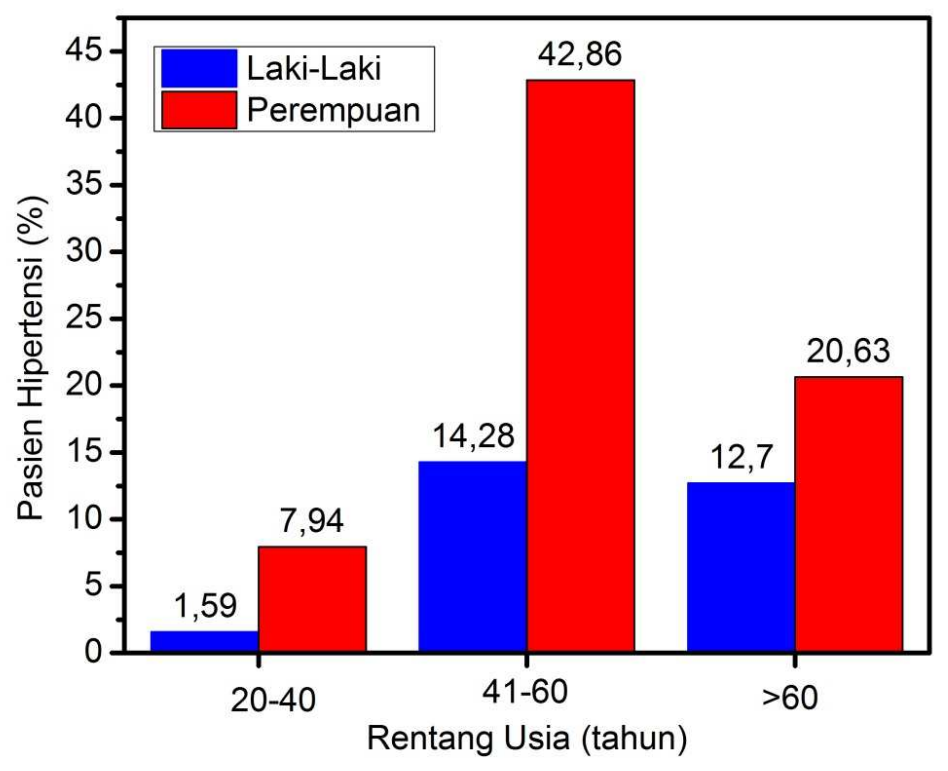

Gambar 1. Pasien Hipertensi berdasarkan Jenis Kelamin dan Usia

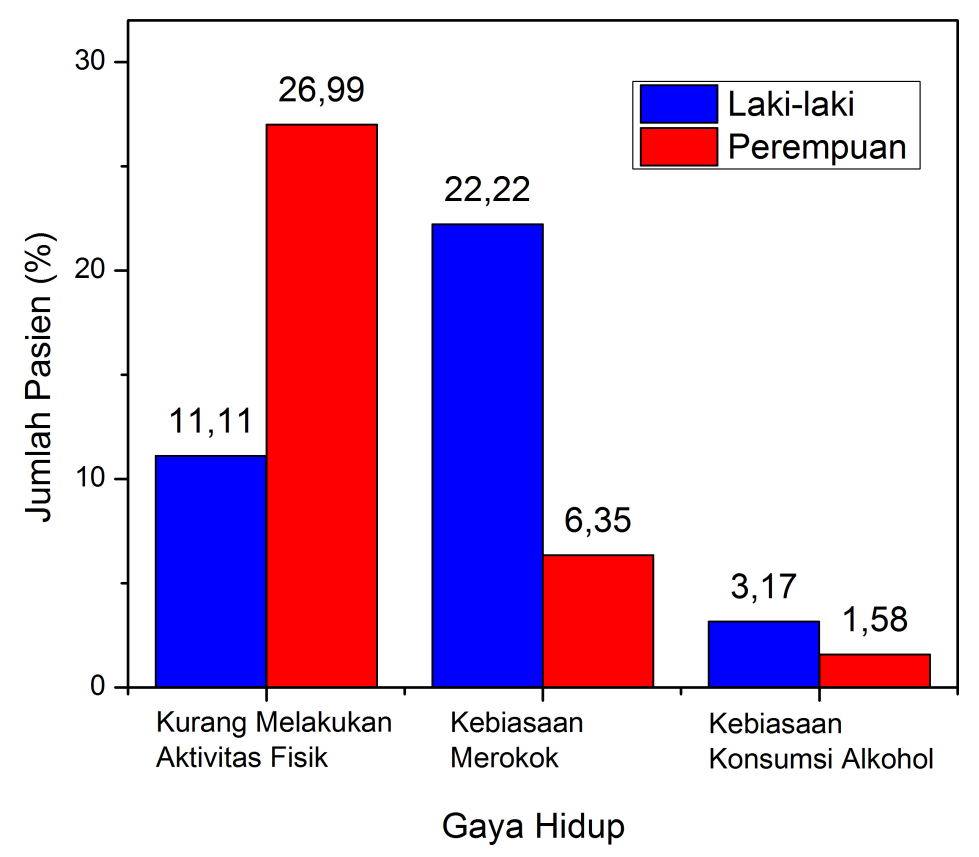

Gambar 2. Pasien Hipertensi berdasarkan Gaya Hidup 
Berdasarkan Gambar 2 diketahui bahwa pasien hipertensi dengan gaya hidup kurang sehat lebih didominasi oleh laki-laki. Gaya hidup yang kurang sehat seperti konsumsi natrium, konsumsi rokok, konsumsi alkohol, obesitas, stres emosional dan kurang melakukan aktivitas merupakan faktor resiko bagi timbulnya hipertensi pada seseorang.

Rutin melakukan aktivitas fisik dapat mengurangi resiko hipertensi mencapai 19 - $30 \%$. Berdasarkan data dari JNC VII, aktivitas fisik aerobik secara teratur paling sedikit 30 menit per hari dapat menurunkan tekanan darah sistol $4-9 \mathrm{mmHg}$. Aktivitas fisik yang dilakukan secara teratur dapat menurunkan tahanan perifer dan melatih otot jantung sehingga otot jantung terbiasa mendapatkan pekerjaan yang lebih berat pada kondisi tertentu. Selain itu, olahraga teratur akan merangsang pelepasan endorfin (morfin endogen) yang menyebabkan relaksasi otot sehingga tekanan darah tidak meningkat (Sihombing, 2010).
Rokok dapat menyebabkan tekanan darah meningkat karena nikotin yang terdapat dalam rokok dan karbon monoksida yang dihisap melalui rokok akan masuk ke aliran darah yang kemudian dapat merusak lapisan endotel pembuluh darah arteri dan menyebabkan artereosklerosis dan tekanan darah tinggi. Rokok juga merangsang pelepasan adrenalin sehingga meningkatkan tekanan darah, denyut nadi dan kontraksi otot jantung (Tawbariah, 2013).

Konsumsi alkohol lebih dari 2-3 gelas sehari untuk perempuan dan 3-4 gelas sehari untuk laki-laki dapat meningkatkan resiko terjadinya hipertensi dan stroke. Mekanisme alkohol dapat meningkatkan tekanan darah belum diketahui secara pasti.

Gambaran distribusi pasien hipertensi di Puskesmas Temindung berdasarkan adanya riwayat keluarga yang menderita hipertensi disajikan dalam Gambar 3.

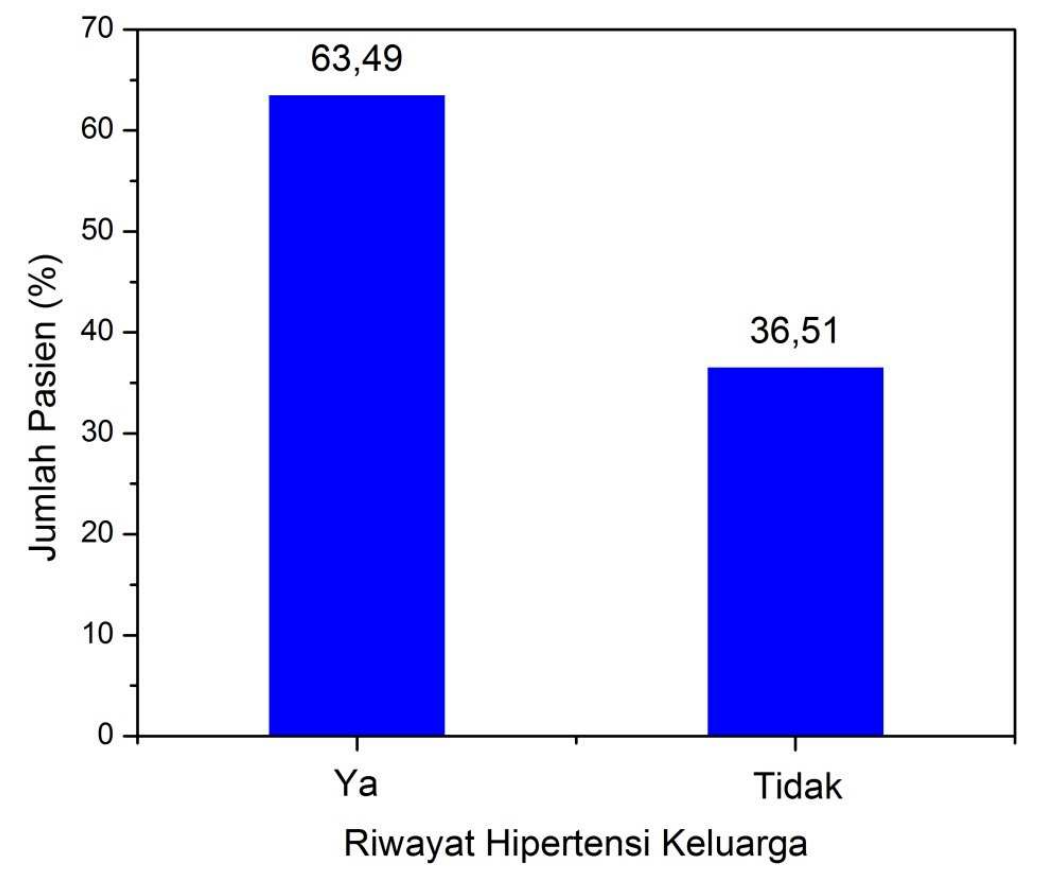

Gambar 3. Pasien Hipertensi berdasarkan adanya Riwayat Hipertensi Keluarga 
Tabel 1.Persentase Kejadian Drug Related Problems (DRPs)

\begin{tabular}{ccccc}
\hline No. & Kategori DRPs & Ya & Tidak & Total \\
\hline 1 & Interaksi Obat & $3(7,5 \%)$ & $37(92,5 \%)$ & $100 \%$ \\
2 & Adverse Drug Reaction & $15(37,5 \%)$ & $25(62,5 \%)$ & $100 \%$ \\
3 & Ketidakpatuhan Pasien & $15(37,5 \%)$ & $25(62,5 \%)$ & $100 \%$ \\
\hline
\end{tabular}

Pada penelitian ini terdapat 63,49 $\%$ pasien yang memiliki riwayat keluarga menderita hipertensi, hal tersebut menunjukkan bahwa faktor genetik memiliki peranan besar dalam terjadinya hipertensi. Menurut Riski Hapsari Nugraha (2010), Angiotensin merupakan prekursor hormon angiotensin II yang dijadikan marker atau pertanda predisposisi genetik pada hipertensi esensial, adapun gen angiotensin ini yaitu $\mathrm{T}_{235}$.

\section{Analisis Drug Related Problems}

Drug Related Problems (DRPs) adalah kejadian yang tidak diharapkan akibat terapi obat sehingga potensial mengganggu keberhasilan terapi yang diinginkan. Kejadian DRPs yang diteliti pada penelitian ini antara lain interaksi obat, adverse drug reaction, dan ketidakpatuhan pasien.Persentase kejadian Drug Related Problems dapat dilihat pada Tabel 1.

Interaksi obat adalah berubahnya efek suatu obat karena adanya obat lain yang diberikan bersamaan. Interaksi dapat terjadi secara farmakokinetik atau farmakodinamik. Interaksi farmakokinetik mempengaruhi proses absorbsi, distribusi, metabolisme dan ekskresi. Interaksi farmakodinamik mempengaruhi ikatan obat dan reseptornya. Interaksi obat juga ada yang menguntungkan dan merugikan (Baxter, 2008).

Berdasarkan Tabel 1, interaksi obat yang potensial terjadi pada pasien hipertensi antara lain interaksi antara amlodipin dan simetidin sebanyak 2 kasus dan interaksi antara parasetamol dan metoklopramida sebanyak 1
kasus.Interaksi antara amlodipin dan simetidin yakni simetidin akan mengurangi metabolisme dan meningkatkan konsentrasi serum amlodipin sehingga dapat meningkatkan efek toksik. Sedangkan interaksi antara parasetamol dan metoklopramida dapat menyebabkan meningkatnya absorbsi parasetamol dan meningkatkan level plasma, hal tersebut kemungkinan karena meningkatnya kecepatan pengosongan lambung. Interaksi tersebut merupakan interaksi farmakokinetik (Baxter, 2008).

Interaksi obat dapat terjadi tetapi tidak selalu berakibat merugikan secara klinis. Secara teoritis interaksi obat tersebut potensial terjadi namun kejadian klinis akibat interaksi obat tidak ditemukan.

Efek Samping obat adalah timbulnya efek yang tidak diinginkan yang timbul dari pemberian obat dengan dosis yang digunakan untuk profilaksis, diagnosis dan terapi. Efek samping tidak mungkin dapat dihilangkan tetapi kejadiannya dapat ditekan atau dicegah dengan menghindari faktor-faktor resiko. Kondisi klinis yang timbul akibat efek samping obat yakni adanya keluhan, gejala atau penyakit baru pada pasien, sehingga hal tersebut menyebabkan meningkatnya biaya pengobatan, mengurangi kepatuhan pasien, dan meningkatkan potensi kegagalan suatu terapi.

Efek samping yang ditemukan dalam penelitian ini yakni 13 pasien mengalami bengkak/nyeri pada persendian karena penggunaan amlodipin, 6 pasien mengalami sakit kepala karena penggunaan amlodipin, 2 
pasien nyeri abdomen karena pemggunaan amlodipin, dan 1 orang mengalami batuk karena penggunaan captopril.

Efek samping nyeri dan pembengkakan pada sendi tangan atau kaki pada penggunaan amlodipin terjadi karena efek vasodilatasi antagonis kalsium dihidropiridin. Efek samping nyeri abdomen terjadi karena saluran cerna dipengaruhi oleh influks ion kalsium. Efek samping sakit kepala terjadi karena dilatasi pembuluh darah/otak. Efek samping batuk dari penggunaan captopril terjadi karena bradikinin tidak terdegradasi dan terakumulasi di saluran pernafasan dan paru.

Salah satu kunci keberhasilan pengobatan suatu penyakit adalah kepatuhan pasien terhadap terapi yang dijalani pasien. Pada penelitian ini ditemukan 37,5\% kasus ketidakpatuhan pasien. Ketidakpatuhan pasien yang paling banyak ditemukan adalah dalam halaturan pakai obat antihipertensi. Adapun beberapa faktor yang diduga menjadi penyebab ketidakpatuhan pasien antara lain tidak mengertinya pasien tentang pentingnya mengikuti aturan pengobatan yang ditetapkan karena hipertensi merupakan penyakit asimptomatik sehingga seringkali pasien menyepelekan penyakitnya padahal obat antihipertensi harus dikonsumsi terusmenerus, kurang pahamnya pasien tentang tujuan pengobatan yakni untuk mencegah morbiditas dan mortalitas organ serta mencegah terjadinya komplikasi, sukarnya memperoleh obat karena obat antihipertensi hanya diresepkan untuk 10 hari, dan kurangnya perhatian/kepedulian keluarga yang mungkin bertanggung jawab atas pemberian obat kepada pasien. Klasifikasi kepatuhan dan tekanan darah akan membantu dokter dalam pengambilan keputusan terapi pasien hipertensi. Pasien yang patuh namun memiliki tekanan darah yang tidak terkontrol perlu dicurigai apakah pasien termasuk dalam kelompok resistensi hipertensi (tekanan darah yang belum terkontrol meskipun telah menggunakan 3 obat antihipertensi yang berbeda golongan) atau terapi yang diberikan kurang optimal. Evaluasi perlu dilakukan agar pasien mendapatkan terapi yang tepat.

\section{KESIMPULAN}

Pasien hipertensi terbanyak adalah pasien wanita dengan usia 41 hingga 60 tahun, pasien yang memiliki gaya hidup kurang sehat $23,80 \%$, pasien yang memiliki riwayat hipertensi keluarga $63,49 \%$.Kejadian Interaksi obat 7,5 \%, Adverse Drug Reaction37,5 $\%$, dan ketidakpatuhan pasien $37,5 \%$.

\section{UCAPAN TERIMAKASIH}

Terimakasih kepada Pimpinan Puskesmas Temindung Samarinda atas izin dan bantuan yang diberikan selama penelitian. Terimakasih kepada dr. Taufansyah atas bantuan yang diberikan dalam penelitian.

\section{DAFTAR PUSTAKA}

1. Baxter, Karen. 2008. Stockley's Drug Interaction. Pharmaceutical Press: London.

2. DEPKES RI. 2013. Riset Kesehatan Dasar. Kemenkes RI: Jakarta.

3. Mutmainah, Nurul., Mila Rahmawati. 2010. Hubungan antara Kepatuhan Penggunaan Obat dan Keberhasilan Terapi Pasien Hipertensi di RSUD Surakarta Tahun 2010. Jurnal Farmasi Indonesia. 11 (2). 51-56.

4. Nugraha, Riski Hapsari., Wahyu Djatmiko., Anton Budi Darmawan. 2011. Perbandingan efektivitas Amlodipine dan Ramipril terhadap Penurunan Tekanan Darah Pasien Hipertensi di RSUD. Prof. Dr. Margono Soekarjo. Mandala of Health. 5 (2). 1-8. 
5. Rahajeng, Ekowati dan Sulistyowati Tuminah. 2009. Prevalensi Hipertensi dan Determinannya di Indonesia.Majalah Kedokteran Indonesia. 59 (12).580-587.

6. Sihombing, Marice. 2010. Hubungan Perilaku Merokok, Konsumsi Makanan/Minuman, dan Aktivitas Fisik dengan Penyakit Hipertensi pada Responden Obes Usia Dewasa di Indonesia. Majalah Kedokteran Indonesia. 60 (9). 406412.
7. Tawbariah., Apriliana., Wintoko., Sukohar. 2013. The Corelation of Consuming Cigarette with Blood Pressure of The Society in Pasaran Island Kota Karang Village East Teluk Betung Sub-District Bandar Lampung. Jornal Faculty of Medicine University of Lampung. 91-98.

8. U.S Department of Health and Human Service. 2003. JNC VII. National Institutes of Health.

9. WHO. 2012. World Health Statistic. 